\title{
Microencapsulation by lyophilization of carotenoids produced by Phaffia rhodozyma with soy protein as the encapsulating agent
}

\author{
Michelle Barboza NOGUEIRA, Caroline Furtado PRESTES ${ }^{1}$, Janaina Fernandes de Medeiros BURKERT ${ }^{1 *}$
}

\begin{abstract}
Carotenoids are pigments that can be applied to food but they are unstable towards certain food intrinsic conditions, as well as processing ones. Microencapsulation is an alternative to increasing their stability. This study aimed to produce carotenoids by Phaffia rhodozyma crops and promote their microencapsulation by lyophilization with soy protein as the wall material, in different proportions. High process yield of $96 \%$ and encapsulation efficiency of around $65 \%$ were observed at the ratios under study. Well-defined and separate micrometer-scale particles with different shapes and sizes were formed and the protection of the compounds of interest was confirmed by differential scanning calorimetry which showed that the endothermic event typical of the free extract after encapsulation - did not occur.
\end{abstract}

Keywords: pigments; microbial cultures; microcapsules.

Practical Application: Microcapsules protecting microbial carotenoids that allow the application in food.

\section{Introduction}

Carotenoids are natural pigments with polyene chains which have from 3 to 15 conjugated double bonds. They are considered bioactive compounds due to their antioxidant capacity, since they neutralize free radicals through the reception of electrons from reactive species (Valduga et al., 2009a; Gonnet et al., 2010). Although these pigments are found in plants, animals and microorganisms, most carotenoids destined to the food industry are obtained by chemical processes (Valduga et al., 2009b), a fact that suggests growing interest in studies of carotenoid production by biotechnological processes (Valduga et al., 2009a).

Phaffia rhodozyma is a GRAS (Generally Recognized as Safe) yeast which has the ability to produce carotenoids intracellularly (Frengova \& Beshkova, 2009). By comparison with other microorganisms and other natural sources, it has advantages, such as the possibility of using alternative inexpensive media, since it requires simple sources of carbon and nitrogen for its growth and little physical space when it comes from crops on an industrial scale, besides being independent of bioproducts seasonality (Cipolatti et al., 2015; Valduga et al., 2009b).

However, regardless of the production source, carotenoids are unstable compounds at high temperatures in the presence of light and oxygen. Thus, it is difficult to maintain their characteristics when they are subjected to certain intrinsic conditions of some products (Bagetti, 2009). An alternative to increasing stability in storage and processing is the use of microencapsulation methods, which consist in the entrapment of compounds in extremely small capsules obtained by different techniques. As a result, encapsulated material may be protected and released in a controlled way under specific conditions so as to expand its application to food (Favaro-Trindade et al., 2008).
Therefore, this study aims to promote the encapsulation of carotenoids produced by $P$. rhodozyma yeast by the lyophilization method with soy protein as the encapsulating agent.

\section{Materials and methods}

\subsection{Microorganism and inoculum preparation}

Phaffia rhodozyma NRRL-Y 17268, a GRAS (Generally Recognized as Safe) yeast from the Northern Regional Research Laboratory (Peoria, USA), was used by this study. The microorganism was kept on sloping agar in malt and yeast (YM) medium with $3 \mathrm{gL}^{-1}$ yeast extract, $3 \mathrm{gL}^{-1}$ malt extract, $5 \mathrm{gL}^{-1}$ peptone and $10 \mathrm{gL}^{-1}$ glucose. Then, $0.2 \mathrm{gL}^{-1} \mathrm{KNO}_{3}$ was added at $4^{\circ} \mathrm{C}$ (Parajó et al., 1998). For reactivation, stock culture tests were performed in test tubes with the same medium and incubated at $25^{\circ} \mathrm{C}$ for $48 \mathrm{~h}$. Cell resuspension was performed in $1 \mathrm{~mL}$ peptone water $(0.1 \%)$, added to $9 \mathrm{~mL} \mathrm{YM} \mathrm{medium} \mathrm{and}$ incubated under the previously described conditions.

\subsection{Production of carotenoids}

The inoculum used for yielding pigments was prepared in $500 \mathrm{~mL}$ Erlenmeyer flasks with $90 \mathrm{~mL}$ YM broth and $10 \mathrm{~mL}$ culture from the reactivation. It was incubated at $25^{\circ} \mathrm{C}, 150 \mathrm{rpm}$ for $48 \mathrm{~h}$ or the period of time needed to reach $1 \times 10^{8} \mathrm{cel} . \mathrm{mL}^{-1}$, counted by the Neubauer chamber (Rios et al., 2015). Bioproduction of carotenoids was carried out in $500 \mathrm{~mL}$ Erlenmeyer flasks with $153 \mathrm{~mL}$ YM production medium, at initial $\mathrm{pH}$ of 6.0 , and $10 \%$ inoculum $\left(10^{8} \mathrm{cel} . \mathrm{mL}^{-1}\right)$. The operating conditions of the process were $25^{\circ} \mathrm{C}, 180 \mathrm{rpm}$ for $168 \mathrm{~h}$ (Rios et al., 2015). The resulting biomasses were dried in an oven at $35^{\circ} \mathrm{C}$ for $24 \mathrm{~h}$. Then, they 
were macerated with mortar and pestle and particle sizes were standardized by a Tyler 115 sieve, corresponding to $>125 \mathrm{~mm}$ (Cipollati, 2012).

\subsection{Extraction and recovery of carotenoids}

Cell disruption was performed by the ultrasonic wave method with $0.01 \mathrm{~g}$ dry biomass (at $35^{\circ} \mathrm{C}$ for $48 \mathrm{~h}$ ); $6 \mathrm{~mL}$ acetone was added to facilitate carotenoid extraction. Ultrasound (4 cycles of $40 \mathrm{kHz}$ ) was applied for $10 \mathrm{~min}$ and water from water baths was replaced at every cycle, according to the method adapted from Medeiros et al. (2008). Each sample was centrifuged at $1745 \mathrm{xg}$ for $10 \mathrm{~min}$. The solvent was separated and the bursting procedure was repeated until the whole cell bleached. In the solvent phases, obtained by centrifugation, $10 \mathrm{~mL} 20 \% \mathrm{NaCl}$ solution (w/v) and $10 \mathrm{~mL}$ petroleum ether were added. After shaking and phase separation, excess water was removed with sodium sulfate $\left(\mathrm{Na}_{2} \mathrm{SO}_{4}\right)$, yielding carotenogenic extracts (Bonfim, 1999). In order to obtain the total volume of carotenogenic extracts to be encapsulated, 5 extractions were performed in each treatment.

\subsection{Microencapsulation of carotenoids and characterization of microcapsules}

Microencapsulation of carotenoids was performed by the lyophilization method, with soy protein as the coating material, according to Pralhad \& Rajendrakumar (2004) and Laine et al. (2008). To prepare the microparticles, the solvent was rotaevaporated from the carotenogenic extracts at $35^{\circ} \mathrm{C}$, followed by dissolution in aqueous solution with the wall material, in the ratios of 1:1 and 1:2 (carotenoids:wall material) in relation to the solid content. The mixture was stirred for $3 \mathrm{~h}$ and then subjected to freezing at $-80^{\circ} \mathrm{C}$, followed by the lyophilization process.

Microcapsule formation, as well as morphological analysis and particle size, was observed by scanning electron microscopy (SEM), according to Castro (2002). Mean particle size was determined by at least 100 measurements performed by the Sigma Scan Pro 5 software.

Carotenoid encapsulation efficiency (EE) was performed according to the spectrophotometric method described by Sutter et al. (2007), based on the estimation of total carotenoids found inside and outside microparticles. To quantify the carotenoids on the surface of the microparticles, $0.1 \mathrm{~g}$ sample and $5 \mathrm{ml}$ hexane were mixed and kept in a vortex shaker for 10 seconds, followed by centrifugation at $3420 \mathrm{xg}$ for 10 minutes. The supernatant was collected. To quantify total carotenoids found inside and outside microparticles, they were dispersed in $5 \mathrm{ml}$ hexane, stirred vigorously for the removal of total carotenoids and filtered with cotton into a $10 \mathrm{ml}$ volumetric flask. The residue was washed with hexane. Both collected fractions were evaluated spectrophotometrically at $470 \mathrm{~nm}$ to obtain total carotenoid content. Results are expressed as a percentage of encapsulated carotenoids by Equation 1:

$\% \mathrm{EE}=\frac{\text { Total Carotenoids }- \text { Surface Carotenoids }}{\text { Total Carotenoids }} \times 100$
Calculation of the yield of the encapsulation process was based on the mass of the initial and final solids followed by conversion to percentage. Confirmation of the encapsulation was performed by differential scanning calorimetry (DSC) analysis according to Rutz (2013) with rate of $10{ }^{\circ} \mathrm{C} \mathrm{min}^{-1}$ between 25 and $280{ }^{\circ} \mathrm{C}$, with a nitrogen flow of $40 \mathrm{~mL} \cdot \mathrm{min}^{-1}$.

Experiments were performed in triplicate and results were statistically evaluated by the analysis of variance. When differences were detected at $5 \%(\mathrm{p}<0.05)$, the $\mathrm{T}$ test was applied.

\section{Results and discussion}

Results of the microencapsulation yield of the lyophilization process with soy protein as the encapsulating agent are shown in Table 1. The highest yields of the microcapsule yields based on the mass of solids in each treatment was $96.40 \%$ in the ratio of $1: 1$ and $97.46 \%$ in the ratio of $1: 2$. It shows that losses of compounds of interest in the process are very small. The same is not observed regarding the efficiency of encapsulation, which considers the percentage of carotenoids protected by the encapsulating agent, since about $65 \%$ of total carotenoids was actually protected by the soy protein. Remaining amounts were dispersed among the microcapsules that were formed and, thus, susceptible to alterations caused by the external environment. The ratio of carotenogenic extract:encapsulating agent did not influence the efficiency of encapsulation, since the percentage of entrapped carotenoids did not differ significantly, suggesting that there is no need to add higher proportion of cover material.

Scanning electron micrographs (SEM) (Figure 1) show characteristic microparticle formation, regardless of the ratio under investigation. Granular material with small, well defined and separate particles, but with quite different shapes, was formed. This fact results from the preparation of the sample and the technique which does not enable particle sizes to be standardized.

Microcapsules had an average size of $12.11 \pm 4.60 \mu \mathrm{m}$ for "a", with variation from 3.73 to $24.10 \mu \mathrm{m}$ and to $11.34 \pm 5.16 \mu \mathrm{m}$ for "b", ranging from 2.69 to $23.21 \mu \mathrm{m}$.

According to Rutz (2013), the acquisition of spherical microparticles depends on the process conditions and the coating. Studies conducted by Sousdaleff et al. (2013), Zuanon et al. (2013) and Rutz et al. (2016) applied the lyophilization method to the encapsulation of different compounds and showed the acquisition of non-characteristic particles. They also showed that microparticle spheres were not formed, suggesting that, depending on the wall material, such conditions are not suitable for obtaining microcapsules, although the method has been commonly used.

DSC thermograms (Figure 2) show endothermic and exothermic events by the representation of downward and upward curves, respectively.

Carotenogenic extracts exhibit an endothermic event at $59^{\circ} \mathrm{C}$. Wall materials have different behavior, since soy protein has two endothermic events at $171^{\circ} \mathrm{C}$ and $226^{\circ} \mathrm{C}$ ( $\mathrm{a}$ and b). When all encapsulated carotenogenic extracts, regardless of the concentration, are observed, there are no endothermic 


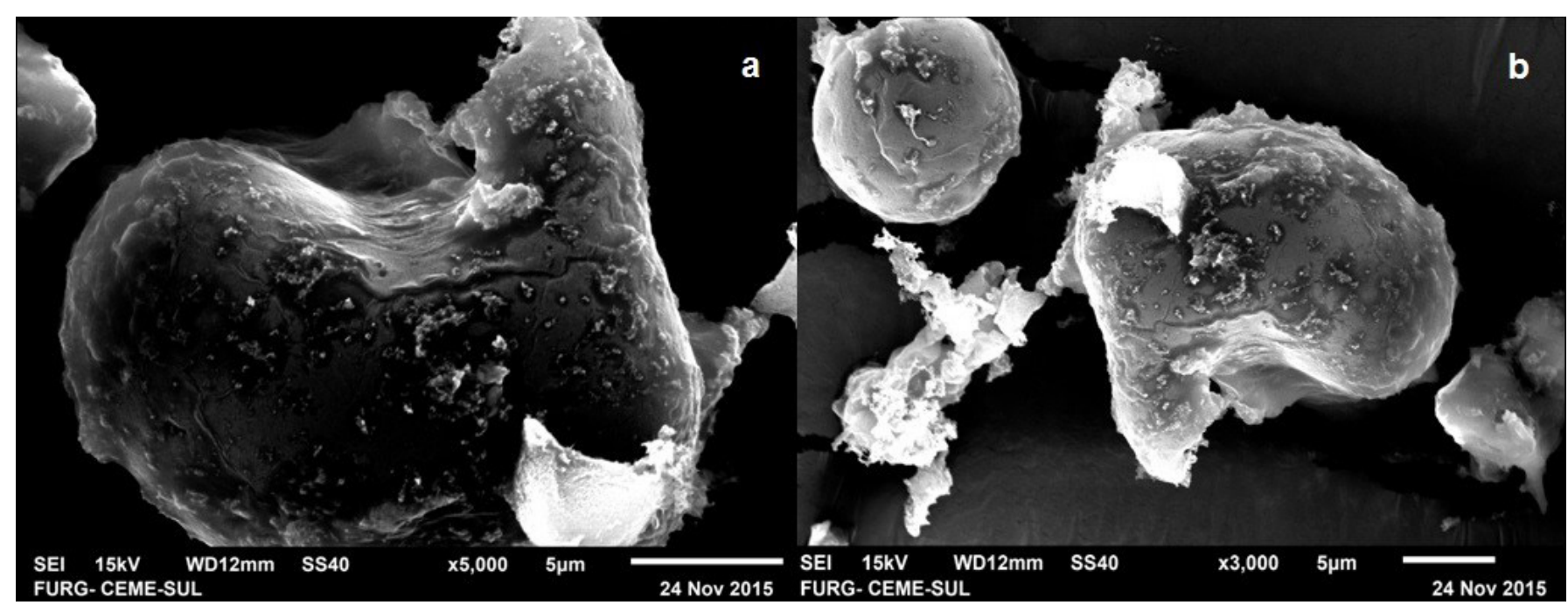

Figure 1. SEM micrographs of carotenoid microcapsules using soy protein, in different proportions, as encapsulating agent: (a) (x 5000) - soy protein $1: 1$; (b) (x 3000) - soy protein.
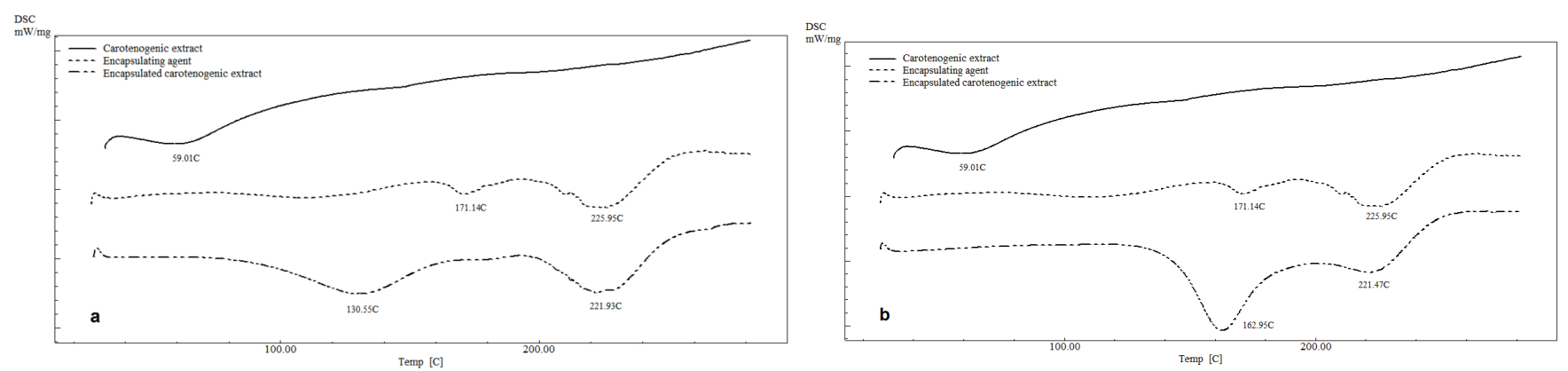

Figure 2. DSC thermograms of the carotenoid microcapsules using soy protein as a coating material in different proportions: (a) soy protein $1: 1$; (b) soy protein 1:2.

Table 1. Encapsulation Efficiency of the lyophilization method.

\begin{tabular}{ccc}
\hline $\begin{array}{c}\text { Encapsulating } \\
\text { agent }\end{array}$ & $\begin{array}{c}\text { Yield of } \\
\text { microcapsules (\%) }\end{array}$ & $\begin{array}{c}\text { Encapsulation } \\
\text { Efficiency (\%) }\end{array}$ \\
\hline Soy protein (1:1) & 96.40 & $65.38 \pm 1.36^{\mathrm{a}}$ \\
Soy protein (1:2) & 97.46 & $65.22 \pm 1.85^{\mathrm{a}}$ \\
\hline
\end{tabular}

Different lowercase letters in the column indicate significant difference by the T Test $(\mathrm{p}<0.05)$.

events at temperatures around $59^{\circ} \mathrm{C}$, which is typical of the free carotenogenic extract. It shows a behavior that resembles the wall materials, suggesting the protection of the compounds of interest and consequent encapsulation.

\section{Conclusion}

Microencapsulation of carotenoids produced by P. rhodozyma yeast with soybean protein as the encapsulating agent by the lyophilization technique was carried out. High process yield and encapsulation efficiency around 65\% were reached, resulting in the formation of well-defined and separate microparticles. Protection of the compounds of interest was successful, indicating the possibility of their application to food.

\section{Acknowledgements}

The authors would like to thank CAPES (Coordination of Improvement Higher Education Personnel) and $\mathrm{CNPq}$ (National Council of Scientific Development) for funding and support.

\section{References}

Bagetti, M. (2009). Caracterização físico-química e capacidade antioxidante de pitanga (Eugenia uniflora L.) (Master's thesis). Universidade Federal de Santa Maria, Santa Maria.

Bonfim, T. M. B. (1999). Produção de astaxantina pela levedura Phaffia rhodozyma (Xanthophyllomyces dendrorhous) a partir de meios de cultura de baixo custo (Ph.D. thesis). Universidade Federal do Paraná, Curitiba.

Castro, L. A. S. (2002). Processamento de mostras para microscopia eletrônica de varredura (Embrapa Clima Temperado Documentos, No. 93). Pelotas: Embrapa Clima Temperado. 37 p.

Cipollati, E. P. (2012). Obtenção de carotenoides microbianos com atividade antioxidante a partir de coprodutos agroindustriais (Master's thesis). Universidade Federal do Rio Grande, Rio Grande.

Cipolatti, E. P., Bulsing, B., Sá, C. S., Burkert, C. A. V., Furlong, E. B., \& Burkert, J. F. M. (2015). Carotenoids from Phaffia rhodozyma: Antioxidant activity and stability of extracts. African Journal 
of Biotechnology, 14(23), 1982-1988. http://dx.doi.org/10.5897/ AJB2015.14682.

Favaro-Trindade, C. S., Pinho, S. C., \& Rocha, G. A. (2008). Revisão: microencapsulação de ingredientes alimentícios. Brazilian Journal of Food Technology, 11(2), 103-112.

Frengova, G. I., \& Beshkova, D. M. (2009). Carotenoids from Rhodotorula and Phaffia: yeasts of biotechnological importance. Journal of Industrial Microbiology \& Biotechnology, 36(2), 163-180. PMid:18982370. http://dx.doi.org/10.1007/s10295-008-0492-9.

Gonnet, M., Lethuaut, L., \& Boury, F. (2010). New trends in encapsulation of liposoluble vitamins. Journal of Controlled Release, 146(3), 276-290. PMid:20600399. http://dx.doi.org/10.1016/j.jconrel.2010.01.037.

Laine, P., Kylli, P., Heinonen, M., \& Jouppila, K. (2008). Storage stability of microencapsulated cloudberry (Rubus chamaemorus) phenolics. Journal of Agricultural and Food Chemistry, 56(23), 11251-11261. PMid:18989975. http://dx.doi.org/10.1021/jf801868h.

Medeiros, F. O., Alves, F. G., Lisboa, C. R., Martins, D. S., Burkert, C. A. V., \& Kalil, S. J. (2008). Ondas ultrassônicas e pérolas de vidro: um novo método de extração de b-galactosidase para uso em laboratório. Quimica Nova, 31(2), 336-339. http://dx.doi.org/10.1590/S010040422008000200028.

Parajó, J. C., Santos, V., \& Vázquez, M. (1998). Optimization of carotenoid production by Phaffia rhodozyma cells grown on xylose. Process Biochemistry, 33(2), 181-187. http://dx.doi.org/10.1016/ S0032-9592(97)00045-9.

Pralhad, T., \& Rajendrakumar, K. (2004). Study of freeze-dried quercetincyclodextrin binary systems by DSC, FT-IR, X-ray diffraction and SEM analysis. Journal of Pharmaceutical and Biomedical Analysis, 34(2), 333-339. PMid:15013147. http://dx.doi.org/10.1016/S07317085(03)00529-6.

Rios, D. A. S., Borba, T. M., Kalil, S. J., \& Burkert, J. F. M. (2015). Parboiling wastewater in the maximization of carotenoids bioproduction by
Phaffia rhodozyma. Ciência e Agrotecnologia, 39(4), 401-410. http:// dx.doi.org/10.1590/S1413-70542015000400011.

Rutz, J. K. (2013). Caracterização e microencapsulação de suco de pitanga roxa (Master's thesis). Universidade Federal de Pelotas, Pelotas.

Rutz, J. K., Borges, C. D., Zambiazi, R. C., Rosa, C. G., \& Silva, M. M. (2016). Elaboration of microparticles of carotenoids from natural and synthetic sources for applications in food. Food Chemistry, 202, 324-333. PMid:26920301. http://dx.doi.org/10.1016/j.foodchem.2016.01.140.

Sousdaleff, M., Baesso, M. L., Medina, A. No., Nogueira, A. C., Marcolino, V. A., \& Matioli, G. (2013). Microencapsulation by freeze-drying of potassium norbixinate and curcumin with maltodextrin: stability, solubility, and food application. Journal of Agricultural and Food Chemistry, 61(4), 955-965. PMid:23256578. http://dx.doi.org/10.1021/ jf304047g.

Sutter, S. C., Buera, M. P., \& Elizalde, B. E. (2007). $\beta$-carotene encapsulation in a mannitol matrix as affected by divalent cations and phosphate anion. International Journal of Pharmaceutics, 332(1-2), 45-54. PMid:17095170. http://dx.doi.org/10.1016/j.ijpharm.2006.09.023.

Valduga, E., Tatsch, P. O., Tiggemann, L., Treichel, H., Toniazzo, G., Zeni, J., Luccio, M., \& Fúrigo, A., Jr. (2009a). Produção de carotenoides: microrganismos como fonte de pigmentos naturais. Química Nova, 32(9), 2429-2436. http://dx.doi.org/10.1590/S010040422009000900036.

Valduga, E., Valério, A., Tatsch, P. O., Treichel, H., Fúrigo, A. Jr., \& Luccio, M. D. (2009b). Optimization of the production of total carotenoids by Sporidiobolus salmonicolor (CBS 2636) using response surface technique. Food and Bioprocess Technology, 2(4), 415-421. http:// dx.doi.org/10.1007/s11947-008-0066-X.

Zuanon, L. A. C., Malacrida, C. R., \& Telis, V. R. N. (2013). Production of turmeric oleoresin microcapsules by complex coacervation with gelatin-gum arabic. Journal of Food Process Engineering, 36(3), 364373. http://dx.doi.org/10.1111/jfpe.12003. 